\title{
Motor neurons in the escape response circuit of white shrimp (Litopenaeus setiferus)
}

Zen Faulkes

Many decapod crustaceans perform escape tailflips involving giant interneurons, which includes a specialized fast flexor motor giant (MoG) neuron, and populations of larger, less specialized fast flexor motor neurons and fast extensor motor neurons. These escaperelated neurons are well described in crayfish (Reptantia), but not in more basal decapod groups. To clarify the evolution of the escape circuit, I examined the fast flexor and extensor motor neurons of white shrimp (Litopenaeus setiferus; Dendrobranchiata) using backfilling. In crayfish, the MoGs in each abdominal ganglion are a bilateral pair of separate neurons. In L. setiferus, the MoGs have massive, possibly syncytial, cell bodies and fused axons. The non-MoG fast flexor motor neurons and fast extensor motor neurons are generally found in similar locations to where they are found in crayfish, but the number of motor neurons in both the flexor and extensor pools is smaller than crayfish. The loss of fusion in the MoGs and increased number of fast motor neurons in reptantian decapods may be correlated with an increased reliance on non-giant mediated tailflipping. 
2 Zen Faulkes

3 Department of Biology, The University of Texas-Pan American

4 Edinburg, Texas

5 U.S.A.

6

7 Corresponding author:

8 Zen Faulkes, Department of Biology, The University of Texas-Pan American, $1201 \mathrm{~W}$.

9 University Drive, Edinburg, TX 78539, U.S.A.

10 Phone 956-665-2614

11 Email zen.faulkes@utrgv.edu 


\section{ABSTRACT}

14 Many decapod crustaceans perform escape tailflips involving giant interneurons, which

15 includes a specialized fast flexor motor giant (MoG) neuron, and populations of larger,

16 less specialized fast flexor motor neurons and fast extensor motor neurons. These

17 escape-related neurons are well described in crayfish (Reptantia), but not in more basal

18 decapod groups. To clarify the evolution of the escape circuit, I examined the fast flexor

19 and extensor motor neurons of white shrimp (Litopenaeus setiferus; Dendrobranchiata)

20 using backfilling. In crayfish, the MoGs in each abdominal ganglion are a bilateral pair of

21 separate neurons. In L. setiferus, the MoGs have massive, possibly syncytial, cell

22 bodies and fused axons. The non-MoG fast flexor motor neurons and fast extensor

23 motor neurons are generally found in similar locations to where they are found in

24 crayfish, but the number of motor neurons in both the flexor and extensor pools is

25 smaller than crayfish. The loss of fusion in the MoGs and increased number of fast

26 motor neurons in reptantian decapods may be correlated with an increased reliance on

27 non-giant mediated tailflipping. 
Decapod crustaceans escape from predators and other sudden stimuli by tailflipping. The neural basis of escape tailflips has been well-studied (Wine \& Krasne

31 1972; Wine \& Krasne 1982; Edwards, Heitler \& Krasne 1999; Krasne \& Edwards 2002;

32 Faulkes 2008), particularly in Louisiana red swamp crayfish (Procambarus clarkii). The core of the escape circuit consists of medial giant interneurons (MGs) and lateral giant

34 interneurons (LGs) that drive fast flexor motor neurons, including a specialized fast 35 flexor motor giant (MoG) neuron. Some of these neurons are found in non-decapod 36 crustaceans (Silvey \& Wilson 1979), indicating that having this escape circuit is an 37 ancestral condition for the decapods.

Crustacean escape behaviour is an excellent model for studying the evolution of neural circuits. First, the behaviour has an obvious survival value (Herberholz, Sen \& Edwards 2004). Second, many of the responsible neurons have no function other than escape. Third, the core neurons responsible for escape should be found in thousands of

42 species. There are over 14,000 decapod crustacean species (De Grave et al. 2009), and perhaps $50 \%$ may have both MGs and LGs (Faulkes 2008). Indeed, many curious features of the neural circuit cannot be understood without thinking about the evolutionary history of the circuit (Edwards, Heitler \& Krasne 1999; Krasne \& Edwards 2002), leading Krasne and Edwards (2002) to write, "it may follow that reasonable

47 understanding of the nervous system may be impossible without evolutionary analysis, 48 a most sobering possibility." Most escape circuit research has been done on crayfish, which belong to

50 Reptantia, a more derived taxon of decapod crustaceans. The more basal decapod 51 taxa, Dendrobranchiata, Caridea, and Stenopodidea (Dixon, Ahyong \& Schram 2003; 
52 Porter, Perez-Losada \& Crandall 2005) are less well studied, but it is already known

53 that these shrimps and prawns differ in several ways from crayfish. First, crayfish

54 neurons are unmyelinated, but giant interneurons are myelinated in all three non-

55 reptantian taxa (Holmes, Pumphrey \& Young 1941; Heuser \& Doggenweiler 1966; Xu \&

56 Terakawa 1999). Because of the combination of giant interneurons and myelin, shrimp

57 giant axons have the fastest conduction velocity known (Xu \& Terakawa 1999). Second,

58 the left and right fast flexor motor giant neurons (MoGs) are separate in crayfish

59 (Mittenthal \& Wine 1978), but the MoG axons fuse in caridean shrimp and prawns

60 (Johnson 1924; Holmes 1942; Friedlander \& Levinthal 1982). Axonal fusion may

61 promote greater synchrony in muscle activation, which should in turn lead to more

62 powerful tailflips. This should reduce response latency, leading to greater chance of

63 escape. It is surprising that this has been lost in crayfish. Third, at the behavioural level,

64 crayfish giant mediated tailflips are stereotyped and propel the animal in a single plane

65 (Reichert \& Wine 1983), but some shrimp can perform a lateral roll during an escape

66 tailflip (Arnott, Neil \& Ansell 1998). It is not known how shrimp achieve this, particularly

67 given the bilateral fusion of the MoG axons.

Dendrobranchiate shrimp are the most basal decapod crustacean taxa (Dixon,

69 Ahyong \& Schram 2003; Porter, Perez-Losada \& Crandall 2005), and thus are in an

70 interesting position for evolutionary studies of the escape response, but little is known

71 about the motor neurons neurons involved in that group. Here, I examine the fast flexor

72 and fast extensor motor systems of white shrimp, Litopenaeus setiferus. Some of this

73 work has been presented in abstract (Faulkes 2007). 

around South Padre Island, Texas, were purchased from commercial seafood stores in

77 Port Isabel, Texas and housed in aquaria. Individuals were anaesthetized by chilling on

78 ice and dissected in physiological saline. The abdominal nerve cord was removed.

79 Neurons were backfilled (Pitman, Tweedle \& Cohen 1972; Quicke \& Brace 1979;

80 Altman \& Tyrer 1980; Jones \& Page 1983). The nerve containing the neurons of interest 81 was placed in a well of petroleum jelly containing $0.3 \mathrm{M}$ solution of either nickel chloride 82 or cobalt chloride, while the remaining tissue was bathed in physiological saline (mM:

$83410 \mathrm{NaCl}, 12.7 \mathrm{KCl}, 10.3 \mathrm{CaCl}_{2}, 10 \mathrm{MgCl}_{2}$, and $14 \mathrm{Na}_{2} \mathrm{SO}_{4}, 10$

84 tris[hydroxymethyl]aminomethane (Trizma Base); $\mathrm{pH}$ adjusted to $\mathrm{pH}$ 7.4). The tissue 85 was incubated in a refrigerator for 7-18 hours, precipitated with ammonium sulfide or 86 dithiooxamide (a.k.a. rubeanic acid; this term is used hereafter), fixed in $4 \%$ formalin in 87 saline, dehydrated with a progressive ethanol series (70\% for 10 minutes, $90 \%$ for 10 88 minutes, $100 \%$ for 10 minutes, and $100 \%$ again for 5 minutes), and cleared in methyl 89 salicylate. When precipitated with ammonium sulfide, neurons containing cobalt or 90 nickel ions turn black or gray. When precipitated with dithiooxamide, neurons containing 91 cobalt ions turn yellow, and those containing nickel ions turn blue (Quicke \& Brace 92 1979; Jones \& Page 1983). Neurons containing some mixture of the two ions turn an 93 intermediate colour, ranging from dark orange to purplish-red (Quicke \& Brace 1979; 94 Jones \& Page 1983).

95 The third nerve (N3) was filled 42 times in 30 abdominal ganglia of 14 96 individuals. The second nerve (N2) was filled 98 times in 61 ganglia of 23 individuals. 
97 Abdominal ganglia 1 through 5 were filled, although most fills were of the anterior four 98 ganglia. Because backfills are often incomplete, the number of cells reported is the 99 maximum number of cells seen across multiple individuals.

100 Cleared backfills were viewed on an Olympus CX41 microscope, and 101 photographed using an attached Olympus C-5050Zoom digital camera. Images were 102 assembled into final figures using Corel Photo-Paint 12. Some large images were 103 stitched together from multiple photographs.

\section{RESULTS}

\section{Fast flexor motor neurons}

The non-MoG fast flexor cell bodies are found in three clusters (Figure 1), as in

107 other decapods (Mittenthal \& Wine 1978). The flexor medial contralateral (FMC) cluster

108 is contralateral and anterior of the filled N3 (in the terminology of Mittenthal and Wine, 109 "posterior" refers to the position of the axon relative to the cell body). The flexor 110 posterior ipsilateral (FPI) cluster is ipslateral and anterior of the filled N3. The flexor 111 anterior contralateral (FAC) cluster of cell bodies is contralateral and posterior to the 112 filled N3. As in other species (Mittenthal \& Wine 1978), there is segmental variation in

113 the number of cell bodies in each ganglion, with the more posterior showing the 114 greatest deviation (Table 1). White shrimp have one or two fewer cell bodies in each 115 cluster than most other decapods examined to date (Table 2). The FMC cell bodies are 116 more widely separated in L. setiferus than crayfish, with one anterior of the MoG cell

117 body and near the midline, and the other more posterior and lateral of the MoG cell 118 body. Although this separation means these two cells would not normally be described 
119 as being in a "cluster," the FMC in other species is rarely a tight grouping of cell bodies.

120 Fast flexor cell bodies are often pairs or singletons, depending on the number,

121 somewhat separated from other cells in the cluster; e.g., Figure 3a, b in Espinoza et al.

122 (2006); see also Mittenthal \& Wine (1978).

123 The MoG cell bodies in L. setiferus have a variegated appearance, irregular

124 shape, and press closely together so that they look like one large mass covering much

125 of the ventral surface of the abdominal ganglion (Figure 2, Supplemental Video 1). They

126 are not two widely separate, bilateral, spherical cell bodies reported in caridean prawns

127 (Holmes 1942). In L. setiferus, each MoG is $\sim 300 \mu \mathrm{m}$ across the ventral surface of the

128 ganglion, and about $100 \mu \mathrm{m}$ when viewed in the sagittal plane. Other fast flexor motor

129 neurons in L. setiferus are $\sim 50-100 \mu \mathrm{m}$ in diameter.

130 Two lines of evidence show the MoG axons are fused bilaterally. First, when the

131 N3 of one side is filled with cobalt chloride and the other N3 is filled with nickel chloride

132 and precipitated with rubeanic acid, the MoG cell bodies are dark red, clearly distinct

133 from the blue and yellow of the other cells filled by a single nerve (Figure 1, Figure 2A,

134 B), indicating they are filled with a mixture of both chemicals. Second, a single medial

135 axon is visible in the cord between ganglia, which bifurcates and leaves both the left

136 and right N3 (Figure 3). Although the MoG cell bodies are pressed so close together to

137 be sometimes indistinguishable as two cell bodies (e.g., Figure 2B), two axons emerge

138 from the MoG cell bodies (Figure 2A), project dorsally a short distance within the

139 ganglion before fusing as previously reported (Johnson 1924; Holmes 1942), continuing

140 into the nerve cord as one axon until slightly anterior of the point where N3 exits the

141 body, when it bifurcates and sends a branch both left and right (Figure 3B, C). 
The fast flexor motor axons appear slightly "haloed" (Figure 3C) compared to the

143 smooth axons seen filled though N2 (Figure 4).

144

145

146

147 afferents (Leise, Hall \& Mulloney 1987). The posterior branch (N2p) contains fast

148 extensor motor neurons (Treistman \& Remler 1975; Drummond \& Macmillan 1998),

149 slow extensor motor neurons (Drummond \& Macmillan 1998), and neurons associated

150 with muscle receptor organs (MROs) (Leise, Hall \& Mulloney 1987).

151

In L. setiferus, N2 splits into two branches very near the ganglion, with the

152 anterior branch slightly thicker than the posterior. Fills from N2a revealed many fine

153 processes projecting to the middle of the ganglion and no cell bodies (Figure 4A). This

154 is a probably a purely sensory branch containing only tactile afferents, as in

155 Pacifastacus leniusculus (Leise, Hall \& Mulloney 1987).

156

Many cell bodies fill through N2p (Figure 4B). Reasonable hypotheses about the

157 identity of cell bodies can be based on their sizes and putative homology with other

158 species (Table 3). Fast extensor motor neurons are usually double or more the

159 diameter of slow extensor motor neurons (Otsuka, Kravitz \& Potter 1967; Wine \&

160 Hagiwara 1977), although the largest slow extensor motor neurons approach the size of

161 the smallest fast extensor neuron (Wine \& Hagiwara 1977; Drummond \& Macmillan

162 1998). Fills of N2p revealed four large cell bodies located along the posterior margin of

163 the ganglion, one contralateral and three ipsilateral, which are putative fast extensor

164 motor neurons. All abdominal ganglia showed this pattern and no segmental variation 
165 was evident. In other decapods, the contralateral cell body is an inhibitory motor neuron

166 and the ipsilateral cell bodies are excitatory motor neurons (Otsuka, Kravitz \& Potter

167 1967; Treistman \& Remler 1975; Wine \& Hagiwara 1977); the same is likely true in $L$.

168 setiferus.

169 The other small cell bodies filling through N2p are located in several places. One

170 is found contralateral and posterior, near the putative fast extensor inhibitor; about 3-5

171 small cell bodies sit along the posterior lateral margin; two are lateral, sitting in the

172 notch between the exit paths of N1 and N2; one small cell body is located anterior of the

173 exit point of $\mathrm{N} 1$ (seen in abdominal ganglia 1 and 2; presence in other ganglia

174 unknown); one small cell body is near the exact center of the ganglion.

175 Two axons from N2p bifurcate near the midline, and send processes both

176 anterior and posterior for unknown distances (Figure 4C). These are almost certainly

177 axons of the stretch receptors of MROs, which have been described in many species,

178 and are almost always present as a pair of bifurcating axons (Sillar \& Heitler 1985a;

179 Leise, Hall \& Mulloney 1987; Wallis et al. 1995).

180 At least three small axons turn posterior and run along the lateral margin of the

181 nerve cord (ganglia 1-3); one exceptionally clear fill in ganglion 1 revealed five such

182 axons. I was unable to fill any cell bodies associated with these axons; fills rarely

183 extended past the exit point of N3. Despite this incomplete picture of their anatomy,

184 these neurons are probably accessory neurons related to the MROs (Wine \& Hagiwara

185 1977; Leise, Hall \& Mulloney 1987). There are 4 accessory neurons in abdominal

186 ganglion 2 of Procambarus clarkii (Wine \& Hagiwara 1977) 
The backfilled axons of fast extensor motor neurons do not have the "haloed"

188 appearance of fast flexor motor neurons.

\section{DISCUSSION}

The fast flexor motor giant neurons (MoGs) in Litopenaeus setiferus have a

191 structure unlike that reported for any other decapod crustacean. Two aspects of the

192 structure of the MoGs suggest that they may be syncytial cells formed by the fusion of

193 many small neurons. First, they are larger than any other fast flexor motor neurons in

194 this or other species, which are usually $\sim 100 \mu \mathrm{m}$ in diameter (Otsuka, Kravitz \& Potter

195 1967; Mittenthal \& Wine 1978; Sillar \& Heitler 1985a; Wilson \& Paul 1987; Espinoza et

196 al. 2006). Second, they are not spherical as most other neuron cell bodies are. Third,

197 their variegated appearance suggests they have a different internal structure than other

198 neurons. The hypothesized syncytial structure is reminiscent of the third-order giant

199 neurons in squid stellate ganglia, which are also syncytial cells formed from many cell

200 bodies, and also involved in an escape response (Young 1936; Young 1939). Annelid

201 worms also have syncytial giant neurons (Nicol 1948; Günther 1975) that are involved

202 in escape responses (Nicol 1948; Günther 1975; O'Gara, Vining \& Drewes 1982).

203 Although the size and hypothesized fusion in the MoG cell body fusion is

204 unexpected, it is consistent with the long-known fusion of the MoG axons in other

205 caridean shrimp species (Johnson 1924; Holmes 1942; Friedlander \& Levinthal 1982).

206 Given that there are genetic mechanisms to fuse the MoG axons during development

207 (Friedlander \& Levinthal 1982), the same mechanisms could be used to fuse cell

208 bodies. Reduction of fusion appears to be an evolutionary trend in the decapods,

209 starting with hypothesized fusion of MoG cell bodies (this study) and axons in 
210 dendrobranchiates (this study; Xu \& Terakawa 1999), to fusion of the MoG axons only

211 in carideans (Holmes 1942), to no MoG fusion in reptantians (Mittenthal \& Wine 1978).

212 The remaining fast flexor and fast extensor motor neurons appear to be found in

213 homologous positions to the better studied reptantian species. In almost every case,

214 there are fewer cell bodies in L. setiferus than in the homologous groups of neurons in

215 most reptantian decapods. If other non-reptantian species have similarly small numbers

216 of motor neurons, it would suggest that duplication of fast abdominal motor neurons

217 occurred during decapod evolution. The loss or reduction of the massive MoG cell

218 bodies may be correlated with the increased number of fast abdominal motor neurons in

219 reptantians: the amount of ganglionic "real estate" consumed by the MoGs may have

220 constrained the addition of any new fast motor neurons.

221 The "haloed" appearance of the fast flexors, but not fast extensors, may be

222 indicative of myelination. In Palaemon serratus, the MoG axons are myelinated in the

223 periphery, and references to other axons of similar size being myelinated suggest the

224 other fast flexor motor neurons are also myelinated (Holmes 1942).

225 The smaller number of fast abdominal neurons might indicate that shrimp have

226 less fine grained control over the fast flexor motor muscles than crayfish. In many

227 reptantian crustaceans, the fast flexor muscles are used in two distinct forms of

228 tailflipping. The MoGs and other fast flexor neurons are used in single stereotyped

229 escape tailflips triggered by giant interneurons. The MoGs are not involved in repetitive

230 variable tailflipping, which is controlled by an undescribed system of non-giant

231 interneurons (Reichert, Wine \& Hagiwara 1981; Reichert \& Wine 1983; Sillar \& Heitler

232 1985b; Wilson \& Paul 1987; Faulkes 2004); non-giant tailflipping would be generated by 
233 the remaining pool of fast flexor motor neurons. A larger pool of motor neurons may

234 allow for some of the fine control necessary for such variability. Previously, I suggested

235 that non-giant tailflipping originated at the base of the decapod clade (Faulkes 2008),

236 but I did not express this hypothesis as tentatively as it should have been. It is not

237 known if non-reptantian decapods have variable, non-giant tailflipping behaviour like

238 many reptantians do. Indeed, the myelination of the entire population of fast flexors and

239 the axonal fusion of the MoGs point to a circuit specialized for explosive starts. It may

240 be that tailflipping cannot occur without activity of the giant neurons in shrimp, and that

241 a small pool of neurons is sufficient to generate shrimps' more consistently explosive

242 tailflips. Alternately, the variation in motor neuron number may be trivial and have little

243 functional impact, because crustacean muscles generally have sparse polyneuronal

244 innervation. In Munida quadrispina, the FAC cluster of fast flexor motor neurons was

245 lost with no visible change in tailflipping behaviour (Wilson \& Paul 1987).

\section{LITERATURE CITED}

247 Altman JS, Tyrer NM. 1980. Filling selected neurons with cobalt through cut axons. In:

$248 \quad$ NJ Strausfeld, TA Miller, eds. Neuroanatomical Techniques, Berlin: Springer$249 \quad$ Verlag, 373-402.

250 Arnott SA, Neil DM, Ansell AD. 1998. Tail-flip mechanism and size-dependent kinematics of escape swimming in the brown shrimp Crangon crangon. The $252 \quad$ Journal of Experimental Biology 201: 1771-1784.

253 De Grave S, Pentcheff ND, Ahyong ST, Chan T-Y, Crandall KA, Dworschak PC, Felder 254 DL, Feldmann RM, Fransen CHJM, Goulding LYD, Lemaitre R, Low MEY, Martin 255 JW, Ng PKL, Schweitzer CE, Tan SH, Tshudy D, Wetzer R. 2009. A 

classification of living and fossil genera of decapod crustaceans. Raffles Bulletin of Zoology Supplement 21: 1-109.

258 Dixon CJ, Ahyong ST, Schram FR. 2003. A new hypothesis of decapod phylogeny. $259 \quad$ Crustaceana 76: 935-975.

260 Drummond JM, Macmillan DL. 1998. The abdominal motor system of the crayfish, 261 Cherax destructor. II. Morphology and physiology of the deep extensor motor 262 neurons. Journal of Comparative Physiology A 183: 603-619.

263 Edwards DH, Heitler WJ, Krasne FB. 1999. Fifty years of a command neuron: the 264 neurobiology of escape behavior in the crayfish. Trends in Neurosciences 22: 153-160.

Espinoza SY, Breen L, Varghese N, Faulkes Z. 2006. Loss of escape-related giant neurons in a spiny lobster, Panulirus argus. The Biological Bulletin 211: 223-231.

268 Faulkes Z. 2004. Loss of escape responses and giant neurons in the tailflipping circuits 269 of slipper lobsters, Ibacus spp. (Decapoda, Palinura, Scyllaridae). Arthropod Structure \& Development 33: 113-123.

271 Faulkes Z. 2007. Motor neurons involved in escape responses in white shrimp, Litopenaeus setiferus. Integrative and Comparative Biology 47: e178.

273 Faulkes Z. 2008. Turning loss into opportunity: The key deletion of an escape circuit in 274 decapod crustaceans. Brain, Behavior and Evolution 72: 351-361.

275 Friedlander DR, Levinthal C. 1982. Anomalous anatomy of identified neurons in the 276 larval prawn: spontaneous and induced by microlesions. The Journal of Neuroscience 2: 121-142. 
278 Günther J. 1975. Neuronal syncytia in the giant fibres of earthworms. Journal of $279 \quad$ Neurocytology 4: 55-62.

280 Herberholz J, Sen MM, Edwards DH. 2004. Escape behavior and escape circuit 281 activation in juvenile crayfish during prey-predator interactions. The Journal of Experimental Biology 207: 1855-1863.

283 Heuser JE, Doggenweiler CF. 1966. The fine structural organization of nerve fibers, 284 sheaths, and glial cells in the prawn, Palaemonetes vulgaris. The Journal of Cell Biology 30: 381-403.

Holmes W. 1942. The giant myelinated nerve fibres of the prawn. Philosophical 293-314.

Holmes W, Pumphrey RJ, Young JZ. 1941. The structure and conduction velocity of the 290 medullated nerve fibres of prawns. The Journal of Experimental Biology 18: 5054.

Johnson GE. 1924. Giant nerve fibres in crustaceans with special reference to Cambarus and Palaemonetes. The Journal of Comparative Neurology 36: 323-

Jones KA, Page CH. 1983. Differential backfilling of interneuron populations based 296 upon axon projections in a lobster abdominal ganglion. Journal of Neurobiology 14: 441-456.

298 Krasne FB, Edwards DH. 2002. Crayfish escape behavior: lessons learned. In: K Wiese, ed. Crustacean Experimental Systems in Neurobiology, Berlin: SpringerVerlag, 3-22. 
301 Leise EM, Hall WM, Mulloney B. 1987. Functional organization of crayfish abdominal 302 ganglia: II. Sensory afferents and extensor motor neurons. The Journal of 303 Comparative Neurology 266: 495-518.

304 Mittenthal JE, Wine JJ. 1978. Segmental homology and variation in flexor motoneurons 305 of the crayfish abdomen. The Journal of Comparative Neurology 177: 311-334.

306 Nicol JAC. 1948. The giant axons of annelids. The Quarterly Review of Biology 23: 291307 323.

308 O'Gara B, Vining EP, Drewes CD. 1982. Electrophysiological correlates of rapid escape 309 reflexes in intact earthworms, Eisenia foetida. I. Functional development of giant nerve fibers during embryonic and postembryonic periods. Journal of

312 Otsuka M, Kravitz EA, Potter DD. 1967. Physiological and chemical architecture of a lobster ganglion with particular reference to gamma-aminobutyrate and glutamate. Journal of Neurophysiology 30: 725-752.

Pitman RM, Tweedle CD, Cohen MJ. 1972. Branching of central neurons: intracellular Neurobiology 13: 337-353. cobalt injection for light and electron microscopy. Science 176: 412-414. neurones using rubeanic acid. Journal of Microscopy 115: 161-163.

322 Reichert H, Wine JJ. 1983. Coordination of lateral giant and non-giant systems in 323 crayfish escape behavior. Journal of Comparative Physiology A 153: 3-15. 
324 Reichert H, Wine JJ, Hagiwara G. 1981. Crayfish escape behavior: neurobehavioral

325

326

327

328

329

330

\section{1}

332

333

334

335

336

337 Treistman SN, Remler MP. 1975. Extensor motor neurons of the crayfish abdomen. analysis of phasic extension reveals dual systems for motor control. Journal of Comparative Physiology A 142: 281-294.

Sillar KT, Heitler WJ. 1985a. The neural basis of escape swimming behaviour in the squat lobster Galathea strigosa I. Absence of cord giant axons and anatomy of motor neurons involved in swimming. The Journal of Experimental Biology 117: 251-269.

Sillar KT, Heitler WJ. 1985b. The neural basis of escape swimming behaviour in the squat lobster Galathea strigosa II. The motor programme and sensory feedback interactions. The Journal of Experimental Biology 117: 271-289.

Silvey GE, Wilson IS. 1979. Structure and function of the lateral giant neurone of the primitive crustacean Anaspides tasmaniae. The Journal of Experimental Biology 78: 121-136. Journal of Comparative Physiology 100: 85-100.

Wallis EJ, Paul DH, Antonsen BL, Hollenberg R. 1995. Variations on a segmental theme: muscle receptor organs and extensor neuromusculature in the squat lobster Munida quadrispina (Anomura, Galatheidae). The Journal of Experimental Biology 198: 2453-2463.

Wilson LJ, Paul DH. 1987. Tailflipping of Munida quadrispina (Galatheidae): conservation of behavior and underlying musculature with loss of anterior contralateral flexor motoneurons and motor giant. Journal of Comparative Physiology A 161: 881-890. 
347 Wine JJ, Hagiwara G. 1977. Crayfish escape behavior I. The structure of efferent and 348 afferent neurons involved in abdominal extension. Journal of Comparative $349 \quad$ Physiology A 121: 145-172.

350 Wine JJ, Krasne FB. 1972. The organization of escape behaviour in the crayfish. The 351 Journal of Experimental Biology 56: 1-18.

352 Wine JJ, Krasne FB. 1982. The cellular organization of crayfish escape behavior. In: DC 353 Sandeman, HL Atwood, eds. Neural Integration and Behavior, New York:

$354 \quad$ Academic Press, 241-292.

355 Xu K, Terakawa S. 1999. Fenestration nodes and the wide submyelinic space form the 356 357 basis for the unusually fast impulse conduction of shrimp myelinated axons. The Journal of Experimental Biology 202: 1979-1989.

358 Young JZ. 1936. The giant nerve fibres and epistellar body of cephalopods. Quarterly $359 \quad$ Journal of Microscopical Science 78: 367.

360 Young JZ. 1939. Fused neurons and synaptic contacts in the giant nerve fibres of $361 \quad$ cephalopods. Philosophical Transactions of the Royal Society of London. Series B, Biological sciences 229: 465-505. 
1

Fast flexor motor neurons in L. setiferus.

Complete fill of all fast flexor neurons, showing both all clusters of motor neuron cell bodies in abdominal ganglia 2 and 3. Cluster labels (FPI, FMC, FAC) shown for cell bodies in blue, filled from nerve shown at right. Bilateral N3 fill of abdominal ganglion 2, with nickel chloride used on N3 shown at right (blue), and cobalt chloride used on N3 shown at left (yellow), precipitated using rubeanic acid. Anterior towards top; ventral view. 


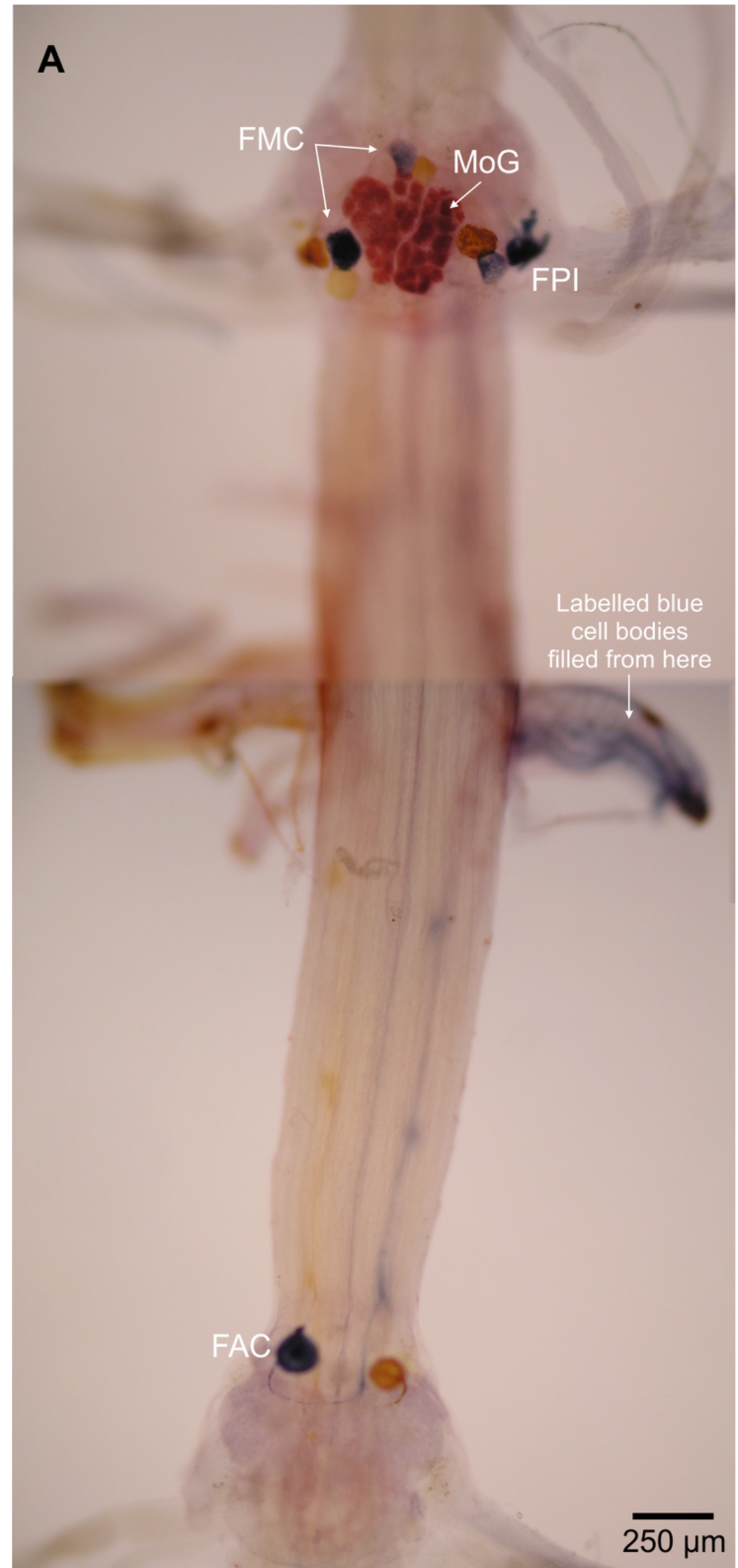

Peer reviewing PDF | (2015:03:4445:1:0:NEW 2 Jun 2015) 
2

Motor giant (MoG) cell bodies in L. setiferus.

(A) Fast flexor neurons in varying focal planes of abdominal ganglion 2. Same individual in Figure 1; ganglion is anterior to filled nerve. (i) Unlabeled image showing MoG detail. (ii-iv) MoG cell body (outlined in ii) and axons, FMC cell bodies, and FPI cell bodies not visible in a single focal plane. Letters identify yellow cell bodies of neurons filled with cobalt chloride from left nerve; numbers identify blue cell bodies of neurons filled with nickel chloride from nerve shown at right. (B) MoG structure in abdominal ganglion 1. (C) MoG structure in abdominal ganglion 3. Bilateral fills using cobalt chloride and nickel chloride precipitated with rubeanic acid in A-B; fills using cobalt chloride precipitated with ammonium sulphide in $C$. Anterior toward top; ventral view. 


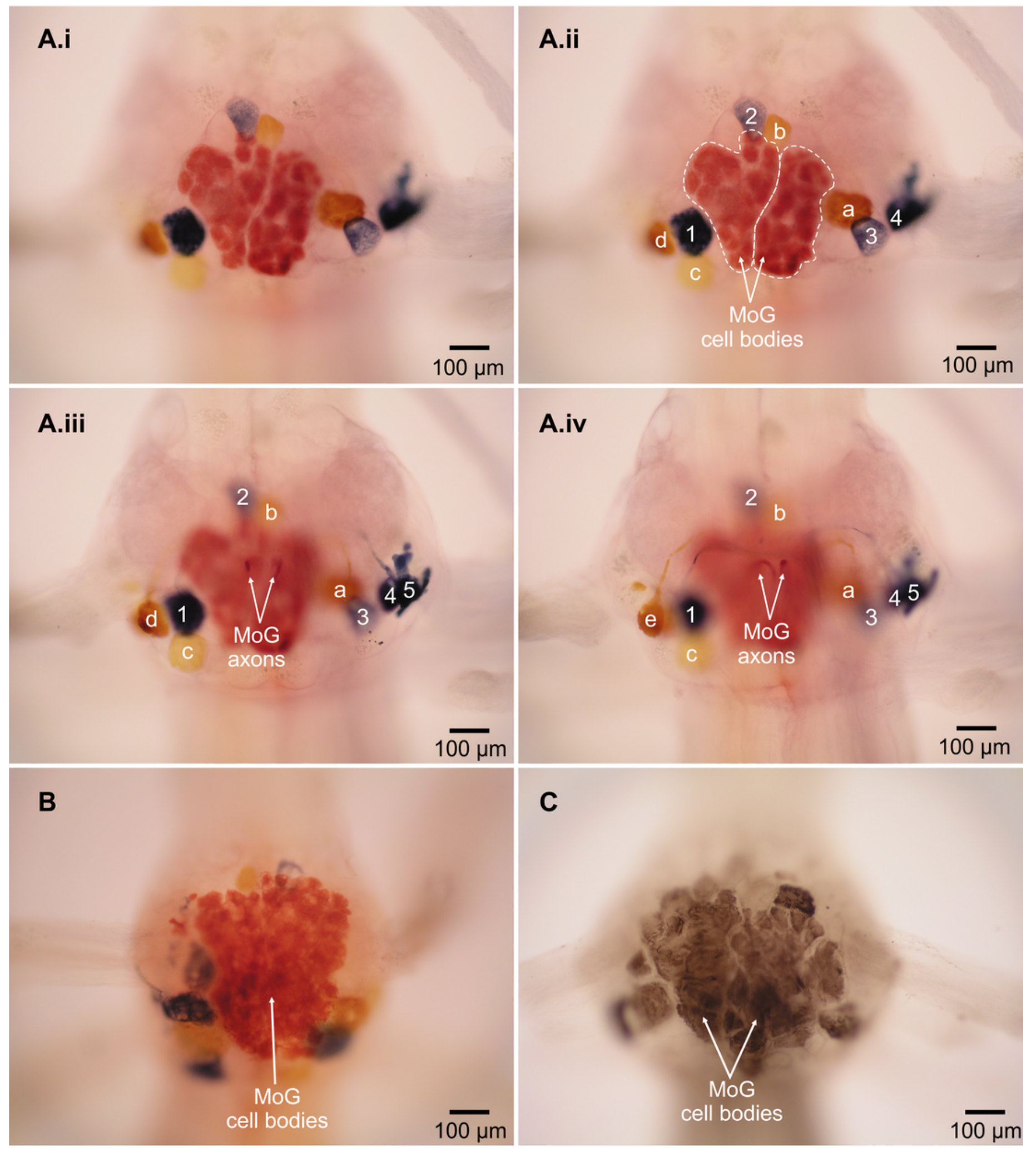




\section{3}

Motor giant (MoG) axons in L. setiferus.

(A) Lateral view of MoG in abdominal ganglion 3, showing axons projecting from ventral cell bodies. (B) Bilateral fill of N3 in abdominal ganglion 3, showing central position of fused MoG axons compared to other fast flexor motor neuron axons. (C) Unilateral fill of abdominal ganglion 1, showing that fill from one side (top of image) results in axon filling that projects out the other, unfilled nerve (bottom). Fills using cobalt chloride precipitated with ammonium sulphide. Anterior towards left of page. Lateral view with dorsal towards top of page in A, ventral view in $B, C$. 

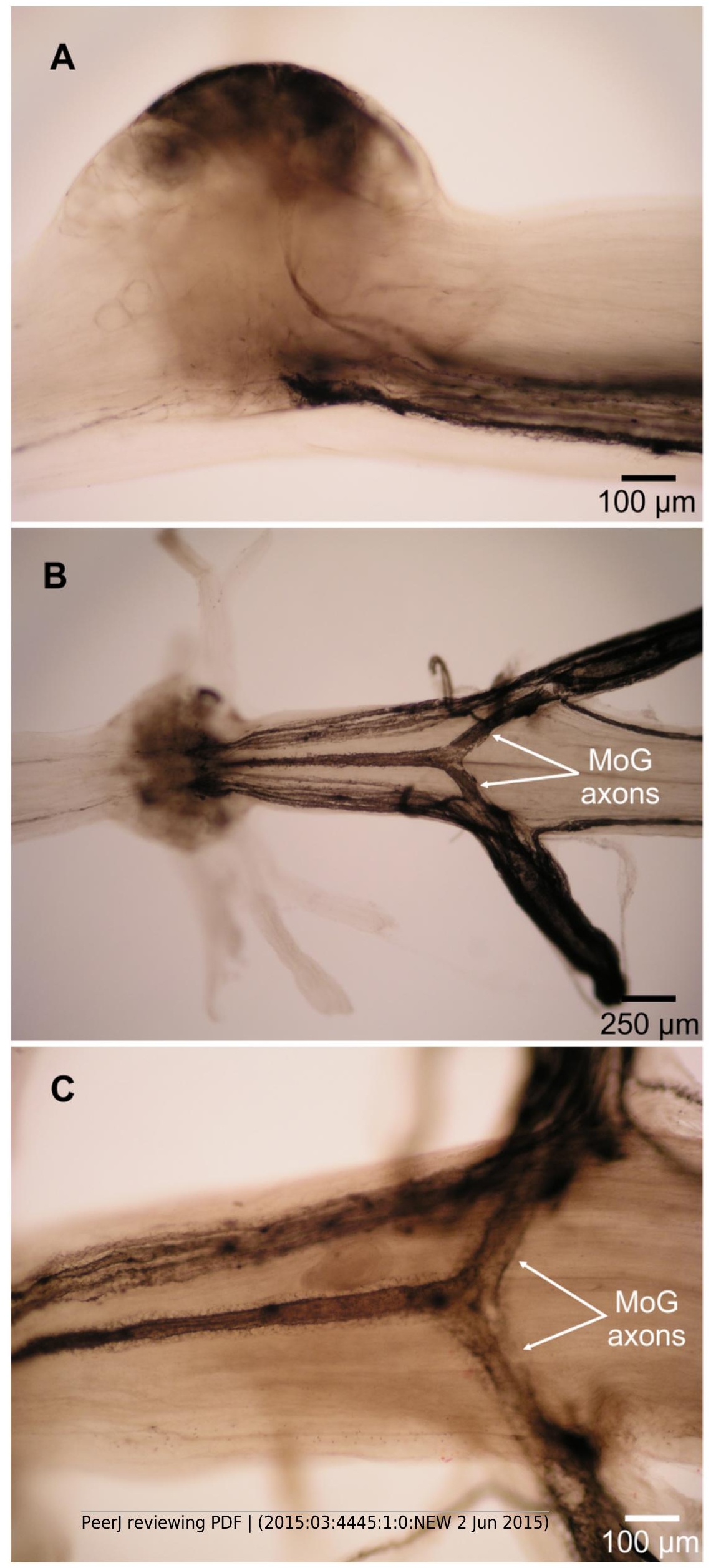


\section{4}

Extensor-related neurons in L. setiferus.

(A, B) Bilateral fill of nerve 2 in abdominal ganglion 1. (A) Putative sensory neurons (blue) filled by anterior branch of nerve 2. (B) Motor neurons (yellow) filled by posterior branch of nerve 2. (C) Muscle receptor organ (MRO) axons (blue) filled through posterior branch of nerve 2 in abdominal ganglion 1 . Fills made using cobalt chloride and nickel chloride precipitated with rubeanic acid. Anterior towards top. 


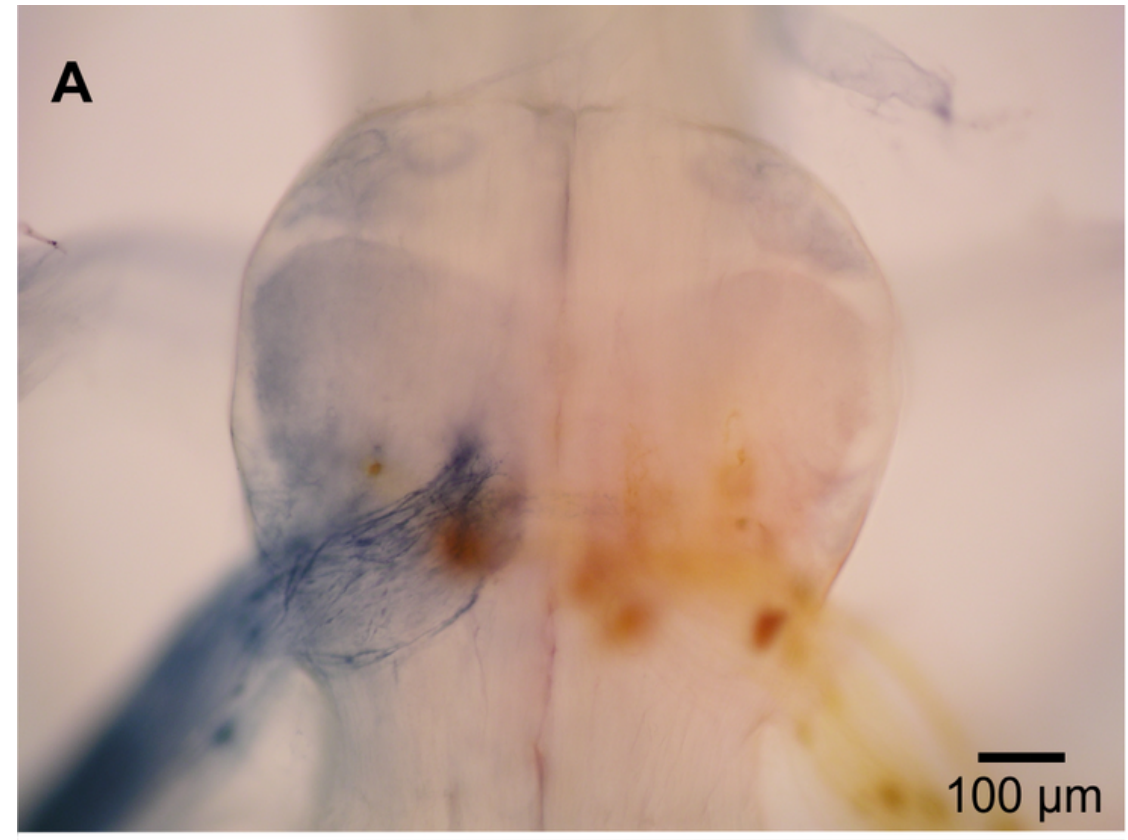

B

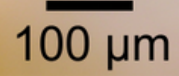

C 


\section{Table $\mathbf{1}$ (on next page)}

Number of fast flexor motor neurons in each abdominal ganglion of $L$. setiferus.

$\mathrm{FMC}=$ flexor medial contralateral; $\mathrm{MoG}=$ motor giant fast flexor motor neuron; $\mathrm{FPI}=$ flexor posterior ipsilateral; $\mathrm{FAC}=$ flexor anterior contralateral 


\begin{tabular}{lllll}
\hline Abdominal ganglia(on) & FMC (Non-MoG) & MoG & FPI & FAC \\
\hline A1-4 & 3 & 1 & 3 & 1 \\
A5 & 3 & 1 & 2 & 0 \\
A6 & $?$ & $?$ & $?$ & 0 \\
\hline
\end{tabular}


Table 2 (on next page)

Number of fast flexor motor neurons in abdominal ganglion 2 of different species.

$F M C=$ flexor medial contralateral; $M o G=$ motor giant fast flexor motor neuron; $F P I=$ flexor posterior ipsilateral; FAC $=$ flexor anterior contralateral. ${ }^{1}$ Espinoza et al., 2006, ${ }^{2}$ Mittenthal and Wine, 1978, ${ }^{3}$ Sillar and Heitler, 1985a, ${ }^{4}$ Wilson and Paul, 1987, ${ }^{5}$ Otsuka et al., 1967, ${ }^{6}$ See discussion in Mittenthal and Wine, 1978 
Species

White shrimp (Litopenaeus setiferus)

Spiny lobster (Panulirus argus) ${ }^{1}$

Crayfish (Procambarus clarkii) ${ }^{2}$

American clawed lobster (Homarus americanus) ${ }^{5} \quad 3$

Squat lobster (Galathea strigosa) ${ }^{3}$

Squat lobster (Munida quadrispina) ${ }^{4}$

\section{FMC (non MoG) MoG FPI FAC}

2

3

3

4

3

$\begin{array}{lll}1 & 3 & 1\end{array}$

$\begin{array}{lll}0 & 4 & 3\end{array}$

143

$\begin{array}{lll}16 & 4 & 3\end{array}$

$\begin{array}{lll}0 & 4 & 2\end{array}$

$\begin{array}{lll}0 & 4 & 0\end{array}$ 


\section{Table 3 (on next page)}

Extensor motor neurons and MRO related neurons of different species.

FEMNs = fast extensor motor neurons; SEMNs = slow extensor motor neurons; $\mathrm{EE}=$ extensor excitors; I = inhibitor. ${ }^{1}$ Treistman and Remler, 1975; Wine and Hagiwara, 1977 (but see Leise et al., 1987, which notes that Wine $\&$ Hagiwara misidentified some extensor neurons), ${ }^{2}$ Leise et al., 1987, ${ }^{3}$ Drummond and Macmillan, 1998a; Drummond and Macmillan, 1998b, ${ }^{4}$ FEMNs: Otsuka et al., 1967, SEMNs: Jones and Page, 1986, ${ }^{5}$ Sillar and Heitler, 1985a; accessory neurons are shown in Figure 9, but the exact number is not mentioned in the text, ${ }^{6}$ Wallis et al., 1995; assignment of fast and slow based on examination of Figure 5. 


\begin{tabular}{|c|c|c|c|c|c|c|}
\hline Species & Ganglia & $\begin{array}{l}\text { Ipsilateral } \\
\text { FEMNs }\end{array}$ & $\begin{array}{l}\text { Contralateral } \\
\text { FEMNs }\end{array}$ & $\begin{array}{l}\text { Ipsilateral } \\
\text { SEMNs }\end{array}$ & $\begin{array}{l}\text { Contralateral } \\
\text { SEMNs }\end{array}$ & $\begin{array}{l}\text { Accessory } \\
\text { neurons }\end{array}$ \\
\hline $\begin{array}{l}\text { White shrimp } \\
\text { (Litopenaeus setiferus) }\end{array}$ & A1-4 & 3 & 1 & $5 ?$ & 1 & 3 \\
\hline 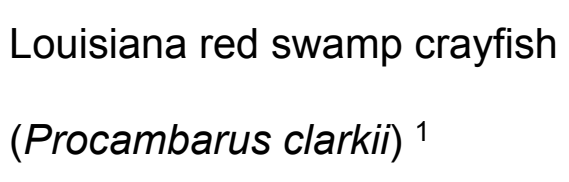 & A1-4 & 5 & $1(\mathrm{I})$ & 5 & 1 & 4 \\
\hline 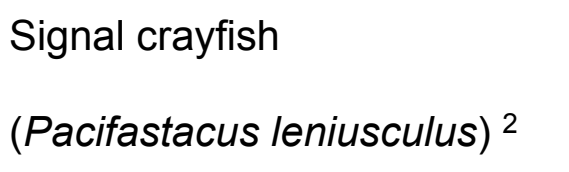 & A2-5 & 5 & 3 & 4 & 1 & 4 \\
\hline $\begin{array}{l}\text { Australian yabby } \\
{\text { (Cherax destructor })^{3}}^{\text {(Che }}\end{array}$ & $\mathrm{A} 3$ & 5 & $1(\mathrm{I})$ & 5 & 1 & 4 \\
\hline $\begin{array}{l}\text { American clawed lobster } \\
{\text { (Homarus americanus })^{4}}^{4}\end{array}$ & A1-4 & $3(\mathrm{EE})$ & $1(\mathrm{I})$ & 4 & 1 & $?$ \\
\hline $\begin{array}{l}\text { Squat lobster } \\
{\text { (Galathea strigosa })^{5}}\end{array}$ & $\mathrm{~A} 2$ & 4-5 (EE) & $1(\mathrm{I})$ & 4 & 1 & $3 ?$ \\
\hline $\begin{array}{l}\text { Squat lobster } \\
\text { (Munida quadrispina) }^{6}\end{array}$ & A2-3 & 4 & 1 & 3 & 1 & 3 \\
\hline
\end{tabular}

